9) Arnstein, Tarbell, Scott, Huang, J. Am. Chern. Soc. 71, 2448 (1949).

10) ! Barltrop, Nicholson, J. Chem. Soc. 1948, 116.

"11) Cook, Somervielle, Nature 163, 410 (1949).

12) Tarbell, Scott, Kemp, J. Am. Chem. Soc. 72, 379 (1950).

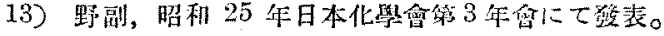

14) Kenner, Turner, J. Chem. Soc. 1911, 2101.

15) Ullmann, Ann. 392, 28 (1904).

16) Weitzenböck, Monàtsch. 34, 217 (1913);

Kenner, $J$. Chem. Soc. 1413, 616.

17) Ross, J. Am. Chem. Soc. 70, 4039 (1948).

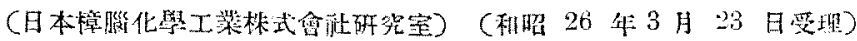

\title{
シネオールの酸化について（第3 報）
}

硝酸に依了酸化

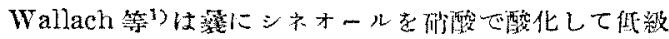

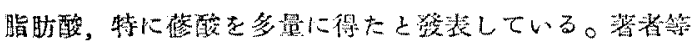

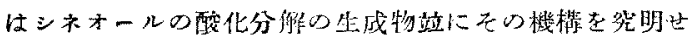

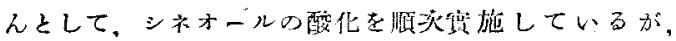

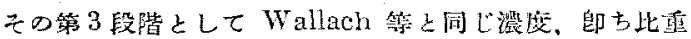
1.15 の酹酸をシネオール 1 mole に湟して 2.5 mole

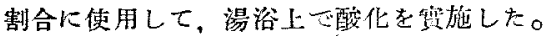

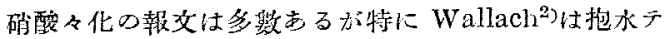
ルビンを确酸て酸化して,氷より重く，且つ石泊エーテル

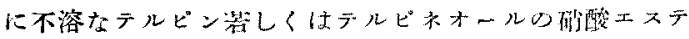
ルを考元られる油状物翼を得，このメステルと照わ机る

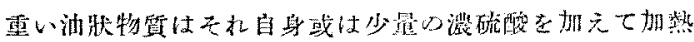

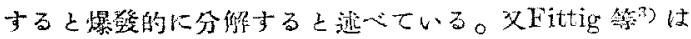

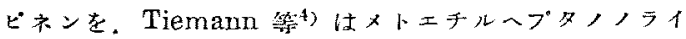
ド(ホモテルペニルメチルタトン)を、文 Baejer は

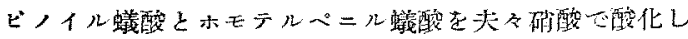
て，何れをデルベニル酸文はテレビン酸索得て居る。

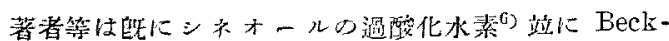

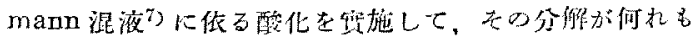

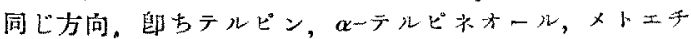

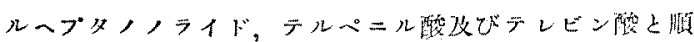

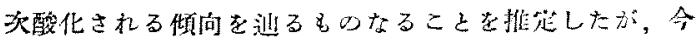

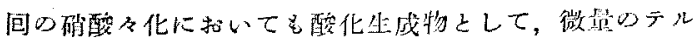

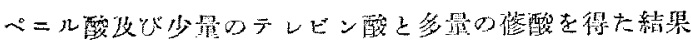

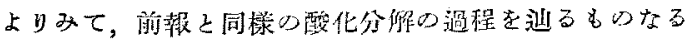
ことが推定さ机た。但しこの場合は亚破酸がス等り慕氣

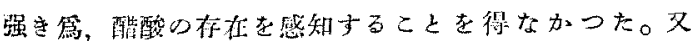

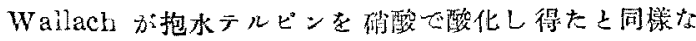

水上り重い油狀物澌が得られ，Wallachはテルビン若し

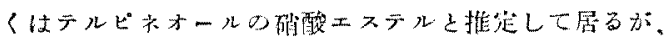

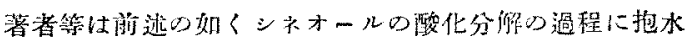

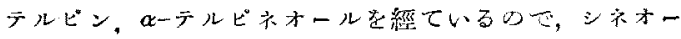
ルの備酸酸化は恰む抱水テルビンの矿酸酸化に類俚して 居ると考え，Wallach の推定を碓加めんとして，この重

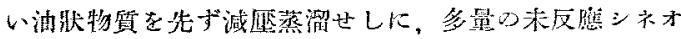

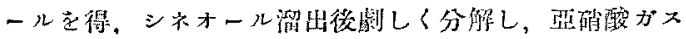

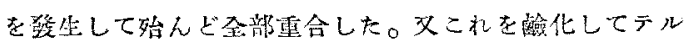
ビン或はテルビネホール老得んと陚みたるも成氻せず。

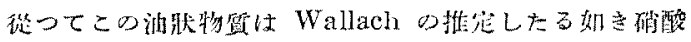

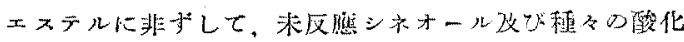

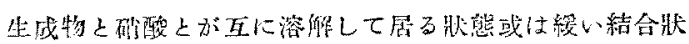

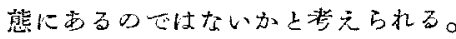

\section{置 驗 $の$ 部}

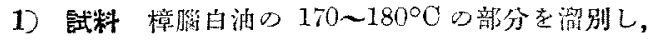

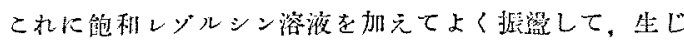

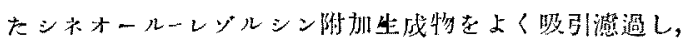

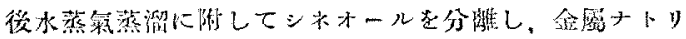

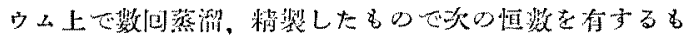
のーむる。 b.p. $172 \sim 173^{\circ} \mathrm{C} ; d_{4}^{25}, 0.9212 ; n \mathrm{D}, 1.4588$ 。

D) 酸化及び生成物の磪認 シネオール30 $\mathrm{g}$ に比重

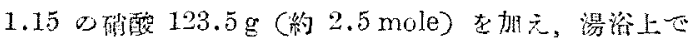

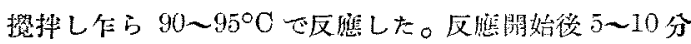
にして砂酸劇しく分解し，反鹪液は一時青線色になり，

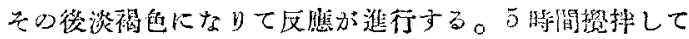

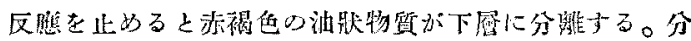




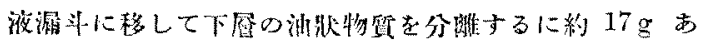

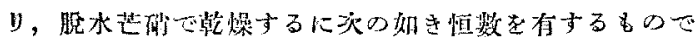
あつた。 $d_{1}^{25}, 1.0686 ; n_{\mathrm{D}}^{25}, 1.4978$ 。

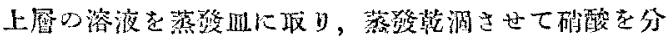
解したるに䘯色のカラメ儿狀の物梊を生じた。これを少

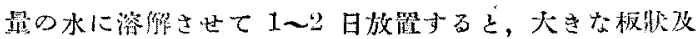

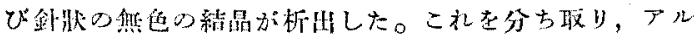

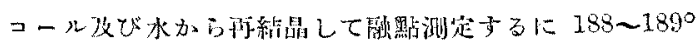

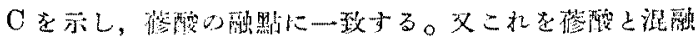
するに融些の降下をみない。從つて多舆に生成したこの

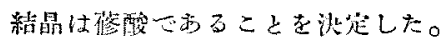

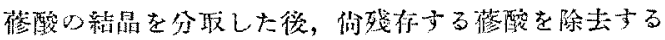

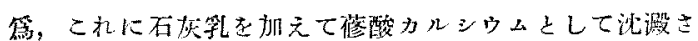

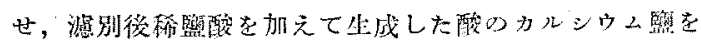

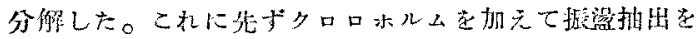
なし，乘にメーテルを加えて上く振凳抽出を行い，何机

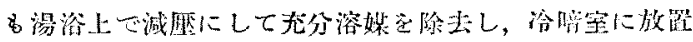
Lt。

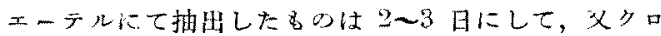

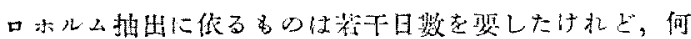

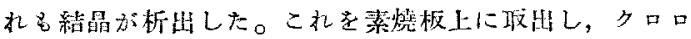

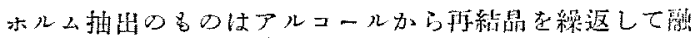
點测定するに，88〜900 C を示してテルペ=ル陑に一致

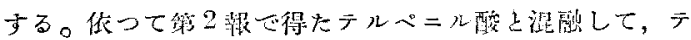

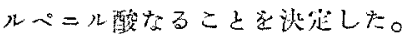

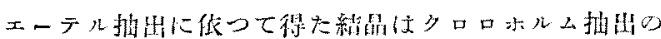

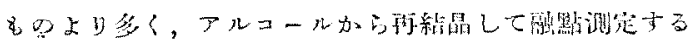

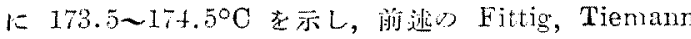

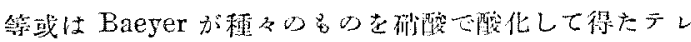

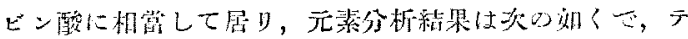
レビン酸勃ることを洮定した。

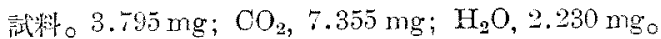

\begin{tabular}{|c|c|}
\hline 潩酸值 & $\mathrm{C}, 52.86 \% ; \mathrm{H}, 6.57 \%$ \\
\hline 諭伯 $\left(\mathrm{C}_{7} \mathrm{H}_{10} \mathrm{O}_{4}\right)$ & $1 \% ; \mathrm{H}, 0.3 \% \%$ \\
\hline
\end{tabular}

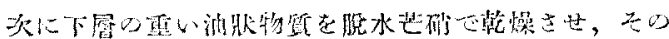

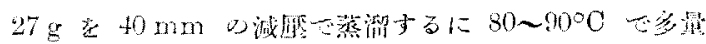

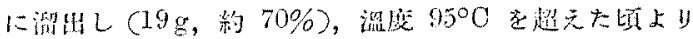

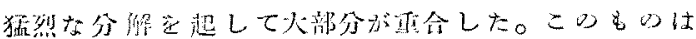

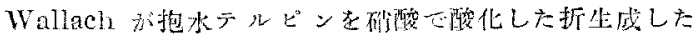

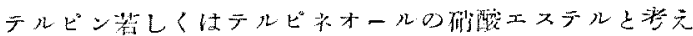

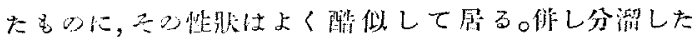

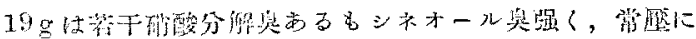

て蒸溜するに $170 \sim 173^{\circ} \mathrm{O}$ 厄 $17 \mathrm{~g}$ 溜出し，沃の恒数を

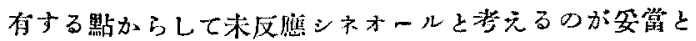
思わ机る。 $d_{4}^{25}, 0.9208 ; n_{\mathrm{D}}^{25}, 1.4579$ 。

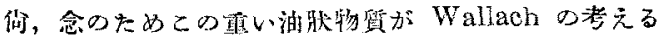

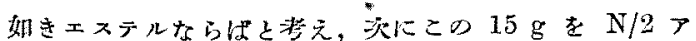

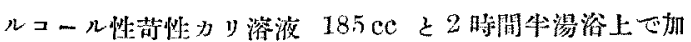

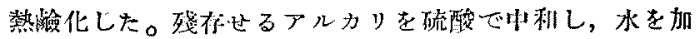

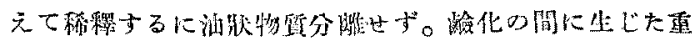

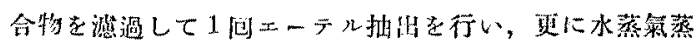
溜に脚した。この溶液は水蒸舜蒸溜に際して非需に發泡

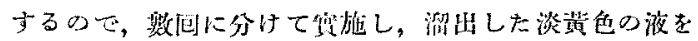

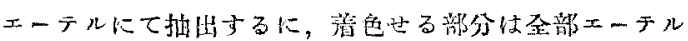

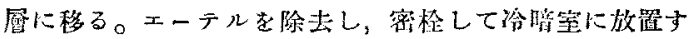

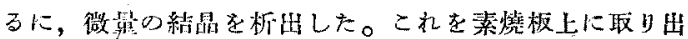

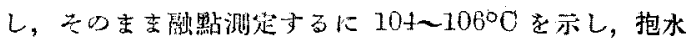

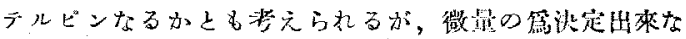
加つた。

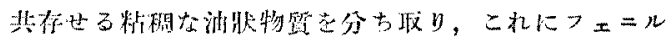

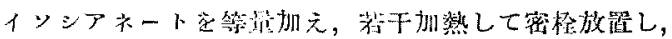
๙゙テルビネオールのフェニルウレタンの生成老檢盗せ しも，認め得なかつた。

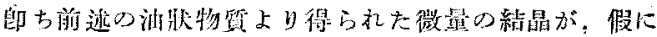
抱水テルピンと沋定し得たとしても，ェステルの形て存 在したものか或はシキホールの矿酸酸化の最初に出來た

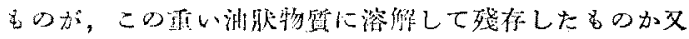

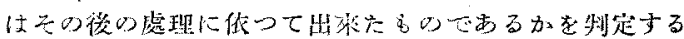

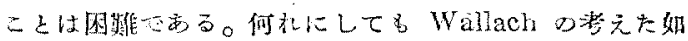

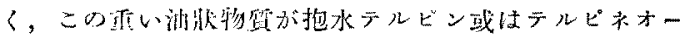

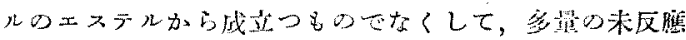

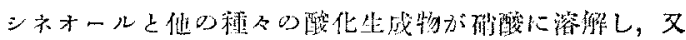

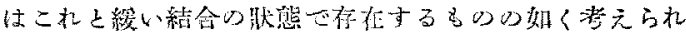
3。

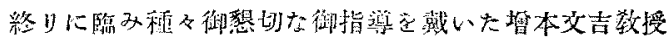
に深㵷する。

\section{一文献 -}

1) Wallach, Brass, 12n, 285, 296 (1881).

2) Wallach, Ann. 239, 19 (1887).

3) Fittig, Mielck, Ann. 180, 47 (1875).

4) Mahla, Tiemann, Ber. 99, 2681 (1896).

5) Baejer, Ber. 29, 1921 (1896).

6) 川本，小倉，目化 72, 520 (1951).

7) 川本，小會，日化 72, 528 (1951). 